\title{
Correction: The induction of core pluripotency master regulators in cancers defines poor clinical outcomes and treatment resistance
}

\author{
A. C. Hepburn ${ }^{1} \cdot$ R. E. Steele ${ }^{2} \cdot$ R. Veeratterapillay ${ }^{3} \cdot$ L. Wilson $^{1} \cdot$ E. E. Kounatidou ${ }^{1} \cdot$ A. Barnard ${ }^{1} \cdot$ P. Berry ${ }^{1}$. \\ J. R. Cassidy ${ }^{1} \cdot$ M. Moad ${ }^{1} \cdot$ A. El-Sherif ${ }^{4} \cdot$ L. Gaughan ${ }^{1} \cdot$ I. G. Mills ${ }^{2,5} \cdot$ C. N. Robson $\mathbb{D}^{1} \cdot$ R. Heer $\mathbb{D}^{1,3}$
}

Published online: 8 May 2019

(c) The Author(s) 2019. This article is published with open access

\section{Correction to: Oncogene \\ https://doi.org/10.1038/s41388-019-0712-y; \\ published online 11 February 2019.}

The original version of this article contained an error in Fig. $5 \mathrm{a}$ where the colours of the labels representing the Hinge and LBD of the AR were incorrect and did not match the corresponding exons. The corrected version of this Figure now appears in the article. The conclusions of this paper were not affected. The authors apologise for this error and any confusion caused.
Open Access This article is licensed under a Creative Commons Attribution 4.0 International License, which permits use, sharing, adaptation, distribution and reproduction in any medium or format, as long as you give appropriate credit to the original author(s) and the source, provide a link to the Creative Commons license, and indicate if changes were made. The images or other third party material in this article are included in the article's Creative Commons license, unless indicated otherwise in a credit line to the material. If material is not included in the article's Creative Commons license and your intended use is not permitted by statutory regulation or exceeds the permitted use, you will need to obtain permission directly from the copyright holder. To view a copy of this license, visit http://creativecommons. org/licenses/by/4.0/.
A. C. Hepburn

anastasia.hepburn@newcastle.ac.uk

$\triangle$ C. N. Robson

c.n.robson@newcastle.ac.uk

$\triangle$ R. Heer

rakesh.heer@newcastle.ac.uk

1 Northern Institute for Cancer Research, Newcastle University, Framlington Place, Newcastle upon Tyne NE2 4HH, UK

2 Prostate Cancer UK/Movember Centre of Excellence for Prostate Cancer, Centre for Cancer Research and Cell Biology, Queen's University of Belfast, Belfast BT9 7AE, UK

3 Department of Urology, Freeman Hospital, The Newcastle upon Tyne Hospitals NHS Foundation Trust, Newcastle upon Tyne NE7 7DN, UK

4 Department of Pathology, Royal Victoria Infirmary, The Newcastle upon Tyne Hospitals NHS Foundation Trust, Newcastle upon Tyne NE1 4LP, UK

5 Nuffield Department of Surgical Sciences, University of Oxford, Oxford OX3 9DU, UK 